\section{Effects of 2,4,5-T and Picloram on Broom Snakeweed in Arizona ${ }^{1}$}

\author{
ERVIN M. SCHMUTZ AND DAVID E. LITTLE
}

\author{
Associate Range Management Specialist, Arizona \\ Agricultural Experimenl Station, Tucson; and \\ Range Conservationist, Bureau of Land \\ Management, Burns, Oregon.
}

\section{Highlight}

Foliar-spray and soil herbicidal treatments were made on broom snakeweed (Gutierrezia sarothrae) in a shortgrass vegetation type in central Arizona. Broom snakeweed was effectively controlled with foliar treatments of $2,4,5$ trichlorophenoxyacetic acid (2,4,5-T) applied at $4 \mathrm{lb} / \mathrm{bcre}$ in April and May. Foliar and soil (granular) treatments of 4-amino-3,5,6-trichloropicolinic acid (picloram) applied at $0.5 \mathrm{lb} /$ acre were effective from February through March and September through December, respectively. Herbicide effectiveness was influenced by soil moisture and stage of plant growth, but apparently was not directly influenced by relative humidity, air temperature, soil temperature, time-of-day of application, or additives of glucose and boron. The effectiveness of $2,4,5-T$ was greatly increased by the addition of $10 \%$ diesel oil in the spray mixture when applied at the rate of $50 \mathrm{gpa}$. The effectiveness of 2,4dichlorophenoxyacetic acid $(2,4-D)$ on snakeweed was similar to that of $2,4,5-T$.

\section{Resumen}

El estudio se llevó a cabo en un tipo de vegetación de zacates cortos en el centro del estado de Arizona tendiente a combatir "Broom snakeweed" (Gutierrezia sarathrae), una hierba tóxica abundante en los pastizales de Estados Unidos y México. La planta fue controlada efectivamente con la aplicación foliar de $4.0 \mathrm{lb}$ /acre de 2,4,5-T durante los meses de abril y mayo, siendo su acción fuertemente aumentada agregando $10 \%$ de Diesel, similar resultado se obtuvo aplicando $0.5 \mathrm{lb}$ /acre de Picloram en forma foliar en los meses de febrero y marzo. Igual dosis, pero de picloram granulado, fue efectivo de septiembre a diciembre. La efectividad del hervicida se vio influida por la humedad del suelo y época de crecimiento de las plantas.

Broom snakeweed (Gutierrezia sarothrae (Pursh) Britt. \& Rusby) is an undesirable poisonous plant that has invaded or increased on millions of acres of depleted western rangelands, especially grasslands (Campbell and Bomberger, 1934; Forest Service, 1937; Humphrey, 1964; Jardine and Forsling, 1922; Nichol, 1952; Parker, 1939; Platt, 1959; Schmutz, Freeman, and Reed, 1968). Improvement of these ranges will usually involve some form of snakeweed control. A method that offers great

\footnotetext{
${ }^{1}$ Contribution from the Department of Watershed Management, Arizona Agricultural Experiment Station, University of Arizona Journal Article No. 1516. Received August 27, 1969; accepted for publication December I, 1969.

Appreciation is expressed to the Bureau of Land Managcment for making available and fencing the site for this study and to the Dow Chemical Co., Midland, Michigan, for furnishing the herbicides used in the experiments.
}

promise is the use of herbicides. To develop an herbicide program, basic studies are needed to determine the most effective time and methods for application of the herbicides.

The objectives of this study were to determinc the effects of the season, time-of-day, rate of application, and level of soil moisture on the susceptibility of broom snakeweed to 2,4,5-trichlorophenoxyacetic acid (2,4,5-T) and 4-amino-3,5,6-trichloropicolinic acid (picloram). Also, the effectivencss of these herbicides was compared to 2,4-dichlorophenoxyacetic acid (2,4-D).

\section{The Study Area and Methods}

The study was conducted in Yavapai County, Arizona in a shortgrass vegetation type one mile south of Cordes, Arizona (Fig. 1). The area, once dominated by blue grama (Bouteloua gracilis (H.B.K.) Lag.) and associated grasses (IIumphrey, 1964, Nichol, 1952), was dominated by snakeweed. The study area was located on a shallow soil on a ridge at an elevation of $3800 \mathrm{ft}$. Slopes varied from 5 to $15 \%$. The shallow soil, derived from schist and granite, was classified as a Balky gravelly loam. ${ }^{2}$ Permanent wilting point (15 atm tension) was at $9.5 \%$ soil moisture.

Climatic data from Cordes shows that precipitation occurs in a summer-winter rainfall pattern and averages about 13 inches annually (Weather Bureau, 1937-1964). The wettest months are December to April and July to September. Mean monthly temperatures vary from a high of $75 \mathrm{~F}$ in July to a low of $47 \mathrm{~F}$ in January. The frost-free period averages 223 days.

The studies were conducted on $12 \times 14-\mathrm{ft}$ plots surrounded by 4 -ft buffer strips. Treatments were randomized and replicated four times. Herbicides used were the propylene glycol butyl ether esters of 2,4-D and 2,4,5-T and the potassium salt of picloram. The 2,4-D and 2,4,5-T were applied as sprays in a $2 \%$ diesel oil-water emulsion at the rate of about 50 gpa. Picloram was applied both in a water spray (50 gpa) and as granules containing $10 \%$ active ingredient. The 2,4-D and 2,4,5-T were applied at the rates of 1 and $4 \mathrm{lb} /$ acre and picloram at 0.5 and $2 \mathrm{lb} /$ acre. The spray was applied at 35 psi with a 4 -ft, two-nozzle, boom sprayer that produced a 7 -ft spray swath. Granules were broadcast by hand. To insure uniform application, each plot was trcated twicc by applying half of the treatment each time. On the date of each application, the time of day, relative humidity, air temperature, and soil temperature were recorded. Also gravimetric soil moisture samples were taken at the 2- and 6-inch depths.

To determine the seasonal susceptibility of snakeweed to 2,4,5-T and picloram, applications were made during 1964 at 2- and 4-week intervals from April through September and 2-month intervals from October through March. Treatments were made near the middle of the day to reduce time-of-day differences in photosynthesis and translocation.

To determine the time-of-day effects of temperature, light intensity, humidity, and soil moisture on herbicide effectiveness, foliar applications of 2,4,5-T were made at 2-hour intervals during the day and at 4-hour intervals at night.

${ }^{2}$ Personal communication from G. Wendt, Soil Scientist, Soil Conservation Service, Prescott, Arizona. 


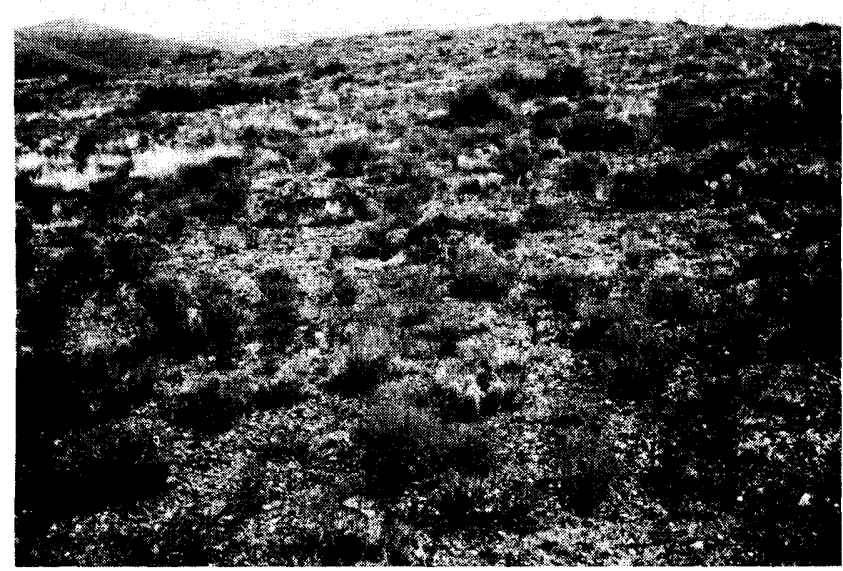

Fig. 1. General view of the study area near Cordes, Arizona. Note the dominant cover of snakeweed and scattered bunches of grass.

Treatments were made during one 24-hour period on September 3 and 4, 1964.

The effect of oil-carrier concentrations on herbicide absorption and effectiveness was determined by applying various amounts of No. 1 diesel oil with 2,4,5-T. 'T he herbicide was applied in $0,2,10$, and $50 \%$ (by volume) diesel oilwater emulsions. Treatments were made on August 13, 1964 during the middle of the day.

A comparison of the seasonal effectiveness of granulated and liquid forms of picloram was made by applying each form near the first day of April (spring), June (summer), September (fall), and December (winter).

The influence of sugar and boron additives on herbicide translocation and effectiveness on broom snakeweed was studied by applying 0,50 , and $500 \mathrm{ppm}$ of borax (sodium tetraborate, $\mathrm{Na}_{2} \mathrm{~B}_{4} \mathrm{O}_{7} \cdot 10 \mathrm{H}_{2} \mathrm{O}$ ) in combinations with 0,10 , and $20 \%$ concentrations of glucose with both 2,4,5-T and picloram. Foliar applications were made during the middle of the day on August 13, 1964.

The effectiveness of different herbicides on snakeweed was compared by making foliar applications of 2,4-D, 2,4,5-T, and picloram on August 12, 1964.

Effects of all treatments were evaluated in April, 1965, by estimating the percentage of plants killed. Estimates were made on ten healthy plants selected at random before treatment on each plot.

\section{Results}

Seasonal Susceptibility.-The seasonal study showed that there were highly significant differences in the effectiveness of the different rates of 2,4,5-T and picloram applied as foliar sprays at different times of the year (Fig. 2). The 4-lb/acre rate of 2,4,5-T produced significant kill of snakeweed (45 to $72 \%$ ) only in the spring months of April and May. Kill was not significant in the summer, fall or winter at the 4-lb rate or at any season of the year at the $1-1 b$ rate.
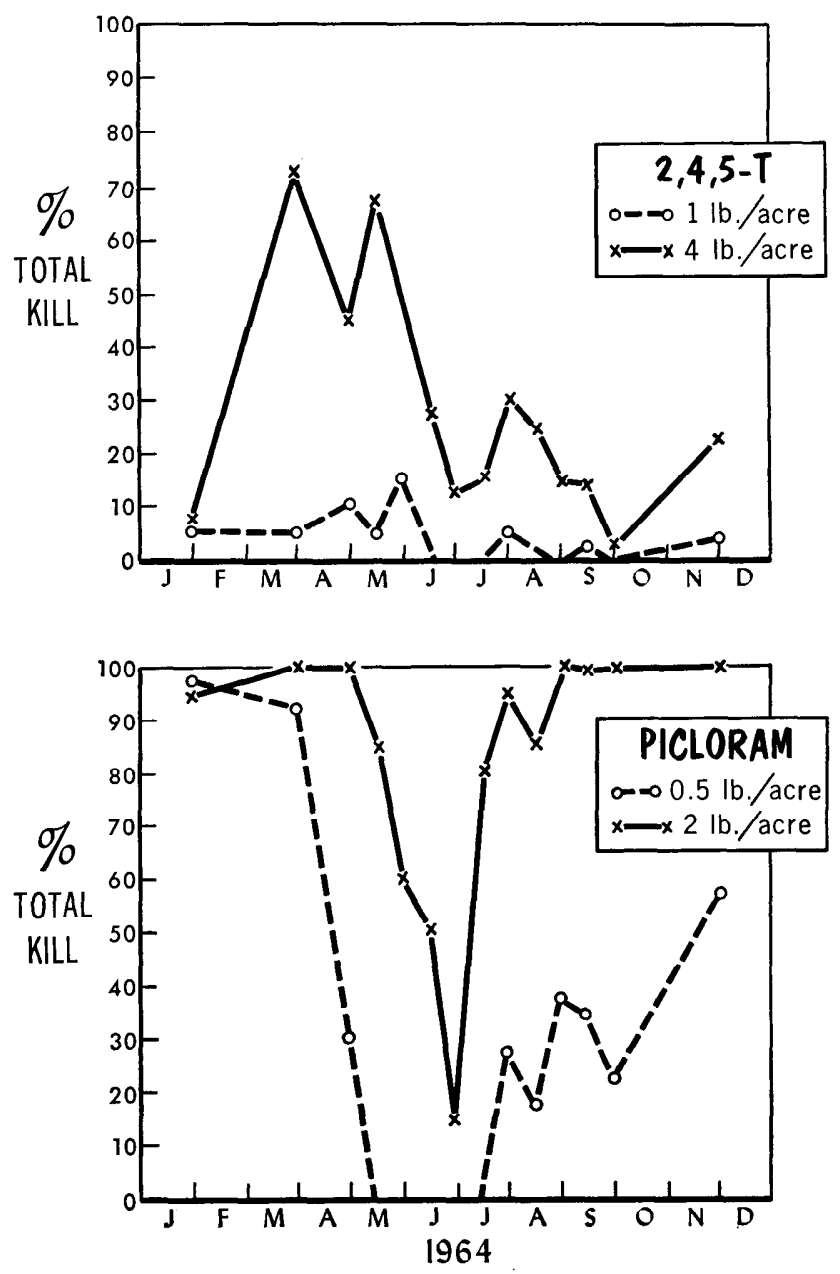

Fic. 2. Seasonal pattern of snakeweed susceptibility to foliar applications of 2,4,5-T and picloram.

Picloram was most effective during February and March, when both rates produced 95 to $100 \%$ kill of snakeweed, and least effective during June and July. The 2-lb rate produced near $100 \%$ kill in the fall and winter; kill at the 0.5 -lb rate was generally less than $40 \%$ in the fall and 60 to $100 \%$ in the winter.

A comparison of the percentages of kill with seasonal soil moisture levels at the 2-and 6-inch depths (Fig. 3) showed that the two were correlated in part. The high rates of kill in the winter and spring by both rates of picloram decreased as soil moisture declined below the wilting percentage during late spring. With the rise in the soil moisture following the summer and fall rains percentage kill returned to a high level at the 2-lb rate but not at the 0.5 -lb rate. Also, summer kill of burroweed by both rates of 2,4,5-T was lower than in the spring. These differences indicate that during the summer and fall some other factor besides soil moisture was limiting the effectiveness of the low rate of picloram and both rates of $2,4,5-\mathrm{T}$. 

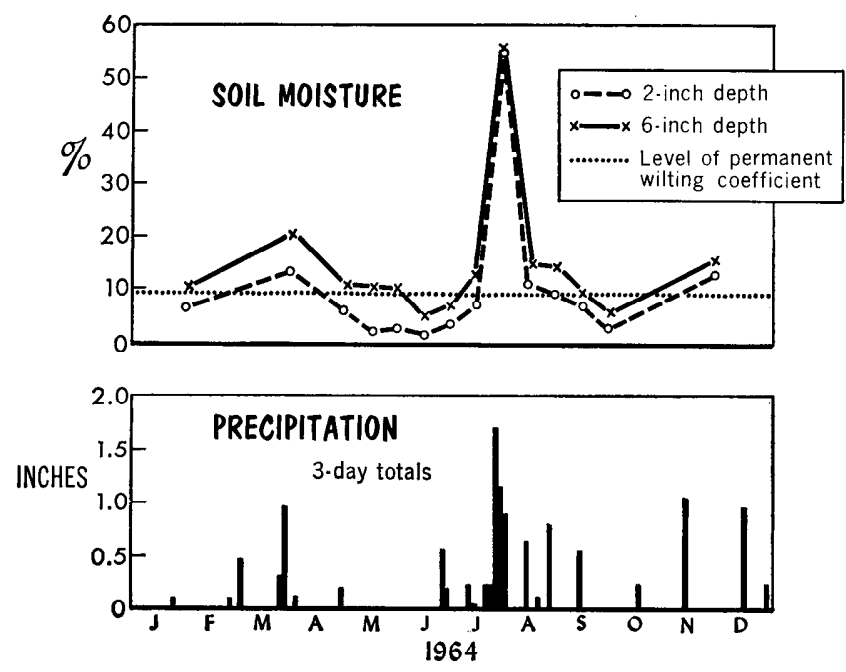

Fic. 3. Precipitation at Cordes, Arizona (Weather Bureau, 1964) and level of soil moisture at times of herbicide treatments.

A possible influence was the stage of plant growth. The percentages of plant kill by the 4 -lb rate of $2,4,5-T$ were greatest during the spring flush of growth and lowest during the dormant periods of the spring drouth and the winter cold. Also, kills were lower during the summer-flowering and fallseeding periods even though soil moisture was as high or higher than in the spring.

Plant responses to picloram were similar except that high plant kill resulted from winter applications at both rates and equally high plant kill resulted from late summer treatments at the high rate of treatment. The greater effect of winter treatments may have resulted from greatcr soil and root absorption (Hamaker et al., 1963) and slower decomposition, and consequently higher retention of the picloram in the plant after treatment which resulted in subsequent death loss during the spring growth season. The lower rate of kill in the summer and fall from the low rate of picloram appeared to be due to stage of growth differences. However, the high rate of picloram treatment appeared to mask effects due to stage of growth.

Comparison of relative humidity, air temperature, and soil temperature data with the percentages of plants killed at different seasons of the year produced no corresponding patterns that would indicate that these factors had any limiting influence on herbicide effectiveness in this study.

Time-of-Day Susceptibility.-The time-of-day study failed to show any significant difference in the effectiveness of 2,4,5-T when applied at different times of the day. This may have been due to the fact that the study was made when snakeweed was low in susceptibility to 2,4,5-T (Fig. 2).

Oil-Carrier Effects.-The oil-carrier study (Fig. 4) showed that the diesel oil concentration had a highly significant influence on the effectiveness

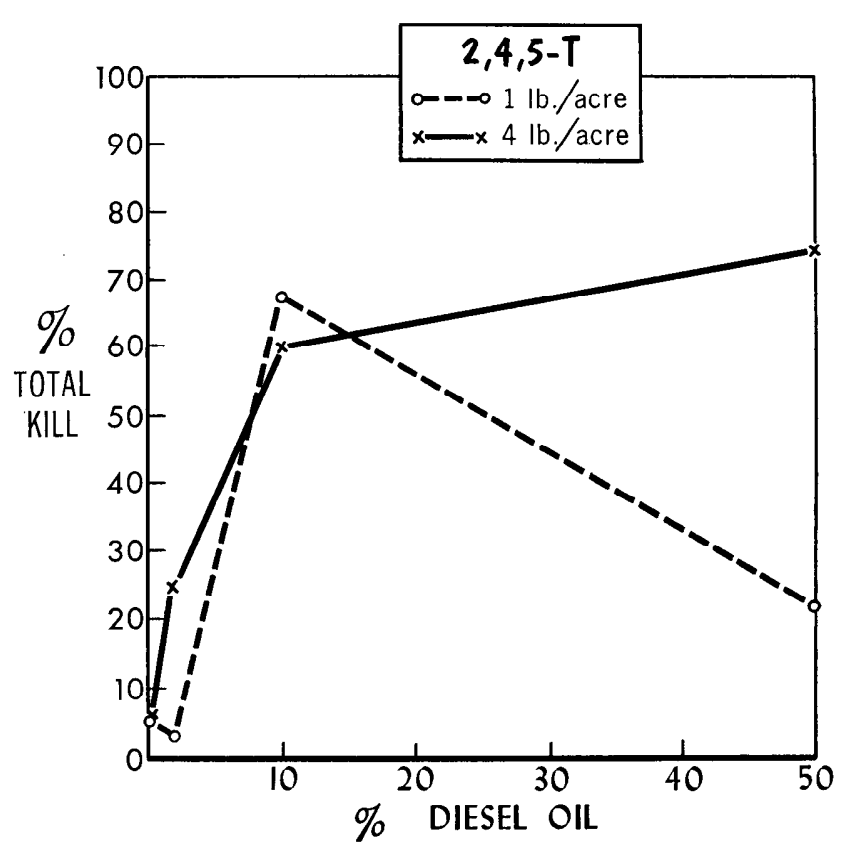

FIG. 4. Influence of the amount of diesel oil in the carrier on the effectiveness of 2,4,5-T on snakeweed.

of $2,4,5-\mathrm{T}$ on snakeweed. The $10 \%$ concentration of oil significantly increased the effectiveness of 2,4,5-T over the 0 and $2 \%$ concentrations at both herbicide rates. A further increase in the oil concentration to $50 \%$ decreased the effectiveness of the herbicide at the $1-1 b$ rate but increased it at the 4 -lb rate. The $10 \%$ rate of diesel oil may have had a direct toxic effect on the snakeweed or may have increased the effectiveness of $2,4,5-\mathrm{T}$ by facilitating its absorption through the stomata of the leaf or its translocation in the plant (Van Overbeek and Blondeau, 1954). The reason for the differential effect of the $50 \%$ rate of oil on the two rates of 2,4,5-T is not known.

Granulated vs Liquid Picloram.-Comparison of the granulated vs liquid forms of picloram on broom snakeweed showed that differences were highly significant and that the effects varied by rate and season of application (Fig. 5).

At the 0.5 -lb rate, the granules had a greater mean effectiveness (64\% kill) than the liquid $(47 \%$ kill), but at the $2-1 b$ rate the liquid $(90 \%$ kill) was more effective than the granules $(83 \%$ kill). Comparisons by dates showed that the low rate of liquid was more effective in the spring than the low rate of granules, but the opposite was true in the summcr, fall, and winter. At the high rate the seasonal effectiveness of the liquid was always equal to or greater than that of the granules. With both granules and liquid, the high rate was more effective than the low rate, except in the fall and winter when differences between the granular rates were not significant. 


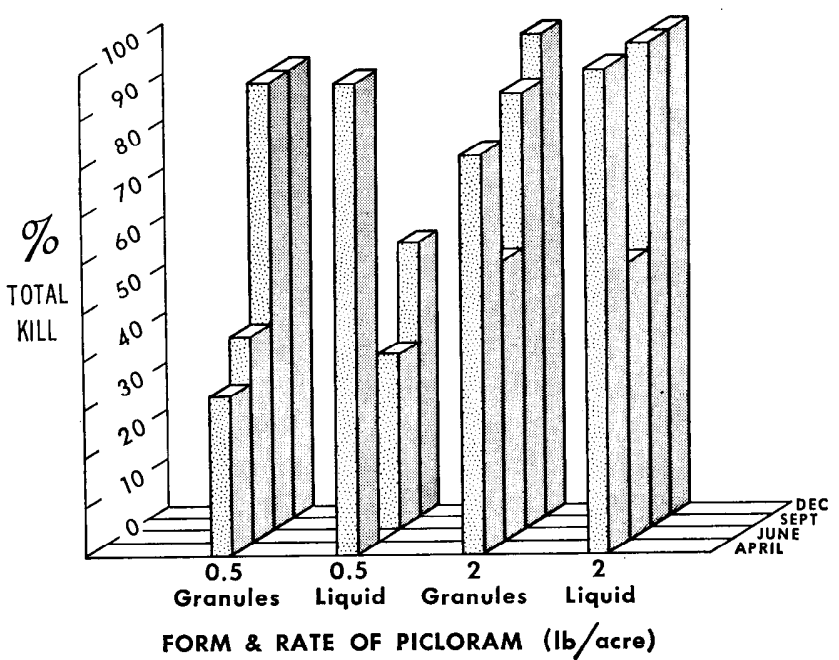

FIG. 5. Influence of season of application on the effectiveness of various forms and rates of picloram in controlling snakeweed.

In all cases the summer applications were least effective. These applications were made during the driest time of the year, approximately six weeks prior to the start of the summer rains. The reduced effectiveness of the herbicide during the summer is believed to have been due to greater sorption of the herbicide by the soil and its degradation by ultraviolet light (Anonymous, 1965).

Other Studies.-Kill of snakeweed from thc herbicide-boron-sugar treatments varied from 0 to $95 \%$ and followed no consistent pattern. The variable results were apparently due to a rain soon after the treatments that washed off portions of the spray before it could be absorbed by the plants.

In the comparison-of-herbicide study, plant kill by the 4-1b/acre rate of 2,4-D (35\%) on August 12 was not significantly greater than the $4-1 b$ rate of $2,4,5-\mathrm{T}(25 \%)$, plant-kills by the $1-1 \mathrm{~b}$ treatments were less than $2 \%$. In contrast plant kill by the $2-1 b$ rate of picloram $(85 \%)$ was significantly greater than that by the 4-1b treatments of 2,4-D or 2,4,5-T and plant kill by the 0.5 -lb treatment of picloram ( $18 \%$ ) was greater than that by the $1-1 \mathrm{~b}$ rate of $2,4-\mathrm{D}$ or $2,4,5-\mathrm{T}$.

\section{Discussion}

These studies showed that in central Arizona broom snakeweed can be effectivcly controlled with 4-lb/acre foliar treatments of 2,4,5-T applied in April and May, with $0.5 \mathrm{lb} /$ acre foliar treatments of picloram from February through March, or with $0.5 \mathrm{lb} /$ acre granular applications of picloram from September through December. Treatment effects were influenced by soil moisture conditions and stage of plant growth, but apparently were not di- rectly influenced by relative humidity, air temperature, soil temperature, time-of-day of application, or additives of glucose and boron. Addition of $10 \%$ dicsel oil in the 2,4,5-T spray, when applied at 50 gpa, increased herbicide effectiveness. The effectiveness of 2,4-D was similar to that of 2,4,5-T.

Picloram was 2 to 4 times more toxic to broom snakeweed than 2,4-D or 2,4,5-T and the season of susceptibility extended over a much longer period. These results were similar to findings on three Chihuahuan Desert shrubs in Arizona (Schmutz, 1967). However, the season of susceptibility contrasted strikingly since the Chihuahuan shrubs were more susceptible in the summer and fall and snakeweed in the winter and spring. The longer season of susceptibility to picloram as compared to 2,4,5-T was probably due to the greater translocation of picloram under moisture stress (Merkle and Davis, 1967).

\section{Literature Cited}

Anonymous. 1965. Tordon information manual, p F-1 to F-3 (revised). The Dow Chemical Co., Midland, Michigan.

Campbell, R. S., ANd E. H. Bomberger. 1934. The occurrence of Gutierrezia sarothrae on Bouteloua eriopoda ranges in southern New Mexico. Ecology 15:49-61.

Forest Service. 1937. Range plant handbook. U.S. Gov. Print. Office, Washington, D.C.

Hamaker, J. W., H. Johnston, R. T. Martin, and C. T. Redemann. 1963. A picolinic acid derivative: a plant growth regulator. Science 141:363.

Humphrey, R. R. 1964. Arizona range resources. II Yavapai County. Arizona Coop. Ext. Service, Agr. Exp. Sta. Bull. A-35. 55 p. (Reprint of Arizona Agr. Exp. Sta. Bull. 229 dated 1950).

Jardine, J. T., And C. L. Forsling. 1922. Range and cattle management during drought. U.S. Dep. Agr. Bull. 1031. $84 \mathrm{p}$.

Merkle, M. G., ANd F. S. Davis. 1967. Effect of moisture stress on absorption and movement of picloram and 2,4,5-T in beans. Weeds 15:10-12.

Nichol, A. A. 1952. The natural vegetation of Arizona. Arizona Agr. Exp. Sta. Tech. Bull. 127. p. 189-230.

PARker, K. W. 1939. The control of snakeweed in the Southwcst. Southwcstcrn Forcst and Rangc Exp. Sta. Res. Note 76. 4 p.

PlatT, K. B. 1959. Plant control-some possibilities and limitations II. Vital statistics of range management. J. Range Manage. 12:194-200.

Schmutz, E. M. 1967. Chemical control of three Chihuahuan Desert shrubs. Weeds 15:62-67.

Schmutz, E. M., B. N. Freeman, ANd R. E. ReEd. 1968. Livestock-poisoning plants of Arizona. The Univ. of Arizona Press, Tucson. $176 \mathrm{p}$.

Van Overbeek, J., And R. Blondeau, 1954. Mode of action of phytotoxic oils. Weeds 3:55-56.

WeAther Bureau. 1937-1964. Climatological data. U.S. Dep. of Commerce, Washington, D.C. (Monthly issues). 